\title{
ТРАНСПОРТНА МЕРЕЖА ЯК ВАЖЛИВИЙ ЧИННИК РОЗВИТКУ ТРАНСКОРДОННИХ РЕГІОНІВ (НА ПРИКЛАДІ ЗАКАРПАТСЬКОЇ ОБЛАСТІ)
}

\begin{abstract}
В статті досліджено особливості формування та експлуатації транспортної мережі в одному із транскордонних регіонів - Закарпатській області. Обтрунтовано актуальність досліджень та основні тендениії розвитку регіональної політики щзодо проблем та перспектив використання транспортної мережі прикордонних територій. Проаналізовано найважливіші Програми та Стратегії Закарпатської області, які охоплюють питання розвитку та відновлення впершу чергу автомобільних доріг загального користування державного значення. Розглянуто проблеми та перспективи розвитку транспортної інфраструктури Закарпатської області в місиях перетину державного кордону.
\end{abstract}

Ключові слова: транспортна інфраструктура, нормативно-правова база, транспортне співробітництво.

Постановка проблеми. Розташування України в Центрально-Східній Європі, протяжність іiі території 3 півночі на південь близько 980 км, а із заходу на схід - 1300 км доводить іï транзитоспроможність та важливість розбудови транспортної мережі. Історичні, економічні, культурні та соціальні зв'язки зумовлюють активізацію транскордонного співробітництва прикордонних територій.

Закарпатська область - «західні ворота» в $\mathrm{CC}$, унікальний регіон України, який межує 3 чотирма-членами $\epsilon \mathrm{C}$, a саме: Польщею, Словаччиною, Угорщиною та Румунією 3 довжиною кордону близько 470 км. Це не тільки можливості успішного транзиту товарів та послуг на європейські ринки, але й фінансова, технічна допомога 3 боку держав-сусідів та відмінний туристичний обмін рекреантами. Нарощування транскордонного співробітництва 3 кожним роком стає все більш актуальним та відповідає основним тенденціям розвитку регіональної політики Закарпаття та України загалом.

Аналіз останніх досліджень та публікацій. Проблеми міжрегіонального та транскордонного співробітництва, роль транспортної інфраструктури починаючи 3 90-х років фундаментально досліджують науковці Інституту регіональних досліджень НАН України у містах Львів та Київ, а також цікавою $з$ наукової точки зору $\epsilon$ низка праць зарубіжних та вітчизняних

(c) Габчак Н.Ф., к.геогр.н., доц. кафедри туризму ДВНЗ «Ужгородський національний університет», E-mail: habchak.nf@gmail.com Маляр Е.М., ст.викл. кафедри туризму ДВНЗ «Ужгородський національний університет», E-mail: dzki@ukr.net вчених, а саме: М.Долішнього, З.Герасимчук, Л.Корольчук, С.Писаренко, І.Артьомова, Н.Габчак, І.Журби, Н.Ільченко, А.Краснейчук, В.Проскура, Т.Ренькас, Я.Малик та інші.

Праці вищезазначених науковців, як правило, присвячені трьом основним аспектам вивчення даної проблематики: перший - розкриває проблеми транскордонного співробітництва, другий - проблеми міжрегіонального співробітництва, а третій - проблеми використання та ефективність експлуатації транспортної інфраструктури в межах досліджуваної території.

Формування цілей статті. Метою статті $\epsilon$ соціально-економічне обгрунтування необхідності розбудови транскордонної транспортної мережі через державний кордон в межах Закарпатської області.

Опис основного матеріалу дослідження. Закарпатська область одна із найменших щодо площі серед областей України (128 тис.км²), займає вигідне економіко - та політикогеографічне положення, орієнтує свої перспективи розвитку на туризм, оскільки іiі туристично-рекреаційний потенціал $є$ вагомим i використовується не в повну силу. Економіка досліджуваної території, порівняно 3 іншими регіонами, є невеликою - у 2016-2017 рр. Валовий регіональний продукт (ВРП) області становив близько 1,4\% валового внутрішнього продукту (ВВП) України. Обсяг ВРП на одну особу у 2017 році склав 34202 грн., що у 2 рази менше, аніж у середньому в Україні. Однак, індекс фізичного обсягу ВРП у розрахунку на одну особу в Закарпатській області впродовж 2014-2017 рр. перевищував середнє значення показника в 
Україні, що $є$ ознакою наявності потенціалу розвитку цього регіону [2].

Транскордонне співробітництво в межах територій досліджень $є$ вагомим інструментом вирішення регіональних проблем. Одним із першочергових та невідкладних завдань $\epsilon$ розвиток регіональної інфраструктури, зокрема, транскордонної, адже до всіх переваг географічного розташування Закарпатської області (сприятливі природно-кліматичні умови, значний природно-рекреаційний потенціал) додаємо, ще одну характерну особливість зовнішньоекономічну і транскордонну орієнтованість эї економіки.

Слід відзначити, що із 16-ти прикордонних областей України особливістю економіки Закарпатської області $є$ найвищий серед інших регіонів рівень експорто- та імпортоорієнтованості. Так, частка експорту у випуску області у 2017 році становила 55,77\% (проти $29,74 \%$ у 2013 році), що у 2,7 рази вище, аніж у середньому в регіонах [2]

Показник частки імпорту у 2017 році становив $50 \%$, що майже на 20\% перевищило значення такого ж показника у Волинській області, економіка якої теж $є$ імпортно-орієнтована. Факт, що зовнішньоекономічна діяльність Закарпатської області повністю зорієнтована на ринок ЄС. Так, на країни ЄC у 2018 році припадало $95,5 \%$ товарного експорту цього регіону, тоді як у середньому в регіонах України - лише 42,6 \%. У географічній структурі товарного імпорту регіону також домінуе продукція 3 країн $\mathrm{CC}$, на яку у 2018 році, припадало 61,3\% [2].

Це проаналізовано економічні чинники, але не менш важливими $\epsilon$ й соціальні. Слід увагу звернути на важливість прикордонного руху в зоні прикордоння. Таку співпрацю значною мірою забезпечує Регламент ЄС №1931/2006 про місцевий прикордонний рух на зовнішніх сухопутних кордонах держав-членів ЄС та про зміни положень Шенгенської Конвенції [4].

Відповідно до даного документа підписано договори про місцевий прикордонний рух з Угорщиною у 2007 році, з Словаччиною та Польщею з 2008 року та Румунією з 2015 року, що дозволило громадянам, які проживають в межах 30-50 км зони від кордону отримати певні переваги щодо перетину митного кордону України [6].

Зокрема, Глава 27 вищевказаної угоди розкриває основні питання щодо транскордонного та регіонального співробітництва, де окреслено найважливіші завдання, а саме:

- Створення сприятливої нормативноправової бази у сфері транскордонного співробітництва;

- сприяння формуванню та розвитку взаємовигідної регіональної політики, зокрема багаторівневого управління та партнерства;

- сприяння економічному та галузевому співробітництву прикордонних територій;

- заохочення розвитку транскордонного співробітництва у сфері транспорту, енергетики, комунікаційних мереж, культури, освіти, туризму, охорони здоров'я, тощо.

Для створення належних умов переміщення пасажиро - та вантажопотоків необхідним $\epsilon$ створення якісної мережі міжнародних транспортних комунікацій різних видів, починаючи 3 контрольно-пропускних пунктів із достатньою пропускною спроможністю й належним транспортним обслуговуванням.

Станом на грудень 2019 року прикордонна інфраструктура на території Закарпатської області включає 19-ть пунктів пропуску, які розташовані вздовж державного кордону 3 країнами-членами $\mathrm{CC}$ (Угорщиною, Словаччиною, Румунією).

Неодноразово на міжнародних рівнях в рамках транскордонного співробітництва актуальними залишаються питання відсутності належної транспортної, виробничої і соціальної інфраструктури, недостатня кількість пунктів перетину кордону, низька пропускна спроможність наявних пунктів пропуску.

Покращення даної ситуації та вирішення вищезазначених проблем можливе через реалізацію важливого програмного документа «Державна цільова економічна програма розвитку автомобільних доріг загального користування державного значення на 2018-2022 роки» [1]. Вона спрямована на: 1) розвиток та відновлення автомобільних доріг загального користування державного значення; 2) інтеграцію до європейської транспортної системи; 3) забезпечення безпеки руху; 4) покращення швидкості та комфортності перевезень тощо.

Реалізація заходів Програми сприятиме: поперше, покращенню транспортно-експлуатаційного стану автомобільних доріг; по-друге, реконструкцію й будівництво нових автомобільних доріг відповідно до європейських стандартів; по-третє, збільшення коштів у бюджет області за рахунок транзитних перевезень; по-четверте, зростання показника пересування туристів на автомобілях.

Програмою передбачено в межах Закарпатської області побудувати нові та якісно проводити експлуатацію наявних автомобільних доріг загального користування державного значення (табл.1): 
Таблиця 1

Перспективи розвитку автомобільних доріг загального користування державного значення на 2018 - 2022 роки (складено за матеріалами [2])

\begin{tabular}{|c|c|c|c|c|}
\hline $\begin{array}{c}\text { Планується } \\
\text { збодувати нові } \\
\text { автомобільні } \\
\text { дороги }\end{array}$ & $\begin{array}{c}\text { Проведення } \\
\text { реконструкції } \\
\text { автомобільних } \\
\text { доріг } \\
\end{array}$ & $\begin{array}{c}\text { Капітальний } \\
\text { ремонт } \\
\text { автомобільних } \\
\text { доріг }\end{array}$ & $\begin{array}{c}\text { Поточний ремонт } \\
\text { автомобільних } \\
\text { доріг }\end{array}$ & $\begin{array}{c}\text { Експлуатаційне } \\
\text { утримання } \\
\text { автомобільних } \\
\text { доріг } \\
\end{array}$ \\
\hline $\begin{array}{l}\text { М-06 Київ - Чоп } \\
\text { (на м. Будапешт } \\
\text { через мм. Львів, } \\
\text { Мукачево і } \\
\text { Ужгород) } \\
\text { (надземні переходи } \\
\text { на під’їді до м. } \\
\text { Житомира та } \\
\text { розв'язки біля с. } \\
\text { Стоянка) }\end{array}$ & $\begin{array}{l}\text { М-06 Київ - Чоп } \\
\text { (на м. Будапешт } \\
\text { через мм. Львів, } \\
\text { Мукачево і } \\
\text { Ужгород) (Львів - } \\
\text { Мукачево - } \\
\text { Ужгород та обхід } \\
\text { м. Житомира) }\end{array}$ & $\begin{array}{l}\text { М-06 Київ -Чоп (на } \\
\text { м. Будапешт через } \\
\text { мм. Львів, } \\
\text { Мукачево і } \\
\text { Ужгород) } \\
\text { (Львівська і } \\
\text { Закарпатська } \\
\text { області) (263,39 км) }\end{array}$ & $\begin{array}{l}\text { М-06 Київ - Чоп } \\
\text { (на м. Будапешт } \\
\text { через мм. Львів, } \\
\text { Мукачево і } \\
\text { Ужгород), (Стрий - } \\
\text { Свалява }\end{array}$ & $\begin{array}{l}\text { М-06 Київ -Чоп (на } \\
\text { м. Будапешт через } \\
\text { мм. Львів, } \\
\text { Мукачево і } \\
\text { Ужгород) } \\
\text { (Львівська область) }\end{array}$ \\
\hline $\begin{array}{l}\text { М-06-01 Київ - Чоп } \\
\text { (Стрий - } \\
\text { Мукачево) }\end{array}$ & $\begin{array}{l}\text { М-06-01 Київ - Чоп } \\
\text { (Стрий - } \\
\text { Мукачево) }\end{array}$ & $\begin{array}{l}\text { М-08 обхід м. } \\
\text { Ужгорода - } \\
\text { контрольно- } \\
\text { пропускний пункт } \\
\text { «Ужгород» } \\
\text { (Закарпатська } \\
\text { область (21,9 км) }\end{array}$ & $\begin{array}{l}\text { М-24 Велика } \\
\text { Добронь - } \\
\text { Мукачево - } \\
\text { Берегове - } \\
\text { контрольно- } \\
\text { пропускний пункт } \\
\text { «Лужанка» } \\
\text { (Мукачево -Чоп) }\end{array}$ & \\
\hline $\begin{array}{l}\text { Н-09 Мукачево - } \\
\text { Рахів - } \\
\text { Богородчани - } \\
\text { Івано-Франківськ - } \\
\text { Рогатин - Бібрка - } \\
\text { Львів (міст через р. } \\
\text { Прут) }\end{array}$ & & $\begin{array}{l}\text { М-23 Берегове - } \\
\text { Виноградів - } \\
\text { Велика Копаня } \\
\text { (Берегове -Вилок) } \\
\text { (40,4км.) }\end{array}$ & $\begin{array}{l}\text { М-25 контрольно- } \\
\text { пропускний пункт } \\
\text { «Соломоново» - } \\
\text { Велика Добронь - } \\
\text { Яноші з під’іздом } \\
\text { до контрольно- } \\
\text { пропускного } \\
\text { пункту «Косини», } \\
\text { Мукачево - Чоп }\end{array}$ & \\
\hline & & $\begin{array}{l}\text { Н-09 Мукачево - } \\
\text { Рахів -Богородчани } \\
\text { - Івано-Франківськ } \\
\text {-Рогатин - Бібрка } \\
\text { — Львів } \\
\text { (Закарпатська, } \\
\text { Івано-Франківська } \\
\text { та Львівська } \\
\text { області) (139,169 } \\
\text { км) }\end{array}$ & $\begin{array}{l}\text { Н-01 Київ - } \\
\text { Знам'янка (Обухів } \\
\text { - Богуслав -Сміла } \\
\text { - Знам'янка) }\end{array}$ & \\
\hline
\end{tabular}


Відповідно до Постанови КМУ «Про затвердження переліку автомобільних доріг загального користування державного значення» від 30 січня 2019 р. № 55 через Закарпатську область із 29 автомобільних доріг міжнародного значення проходить 6, а саме:

- М-06 Київ - Чоп (на м. Будапешт через мм. Львів, Мукачево і Ужгород) протяжністю 891,3 км;

- М-08 Обхід м. Ужгорода - контрольнопропускний пункт «Ужгород» - 17,1 км;

- М-23 Берегове - Виноградів - Велика Копаня - 50 км;

М-24 Велика Добронь - Мукачево Берегове - контрольно-пропускний пункт «Лужанка» - 62,2 км;

- M-25 Контрольно-пропускний пункт «Соломоново» - Велика Добронь - Яноші 3 під'їздом до контрольно-пропускного пункту «Косини» $-58,8$ км;

M-26 Контрольно-пропускний пункт «Вилок» - Вилок - Неветленфолу - контрольнопропускний пункт «Дякове» - 20,5 км [2].

Через територію України проходить 4 транспортних коридора, 1 з яких через Закарпатську область (Коридор №5. Венеція Трієст/Копер - Любляна - Мариборт - Будапешт - Ужгород - Львів - Київ. Національна мережа 5 автомобільного міжнародного транспортного коридору в Україні проходить через: Чоп/Ужгород - Стрий - Львів, з відгалуженням 5а - Сторожниця - Ужгород - Мукачеве, 3 відгалуженням 5b - Косини - Мукачеве. Слід наголосити на тому, що міжнародна автомобільна дорога М-08 в Закарпатській області є частиною 5 Транс'європейського коридору [2].

Відповідно до Угоди між Кабінетом Міністрів України та Урядом Угорської республіки місцем з'єднання на українсько-угорському державному кордоні має бути автомагістраль Західний кордон України - Київ, що проходить територією України та автомагістраль М3, яка проходить територією Угорської Республіки. Таким чином автомагістраль M-3 на території Угорської Республіки, має з'єднатися 3 українською автомобільною дорогою між 212 і 214 км (в районі населеного пункту Дийда) [2].

Також, слід зазначити, що в Закарпатській області у розвитку прикордонної інфраструктури важливе значення відіграють ряд стратегічних та програмних документів регіонального рівня. Регіональна стратегія розвитку Закарпатської області на період до 2020 року виділяе пріоритетом розвиток мереж транспортного сполучення та просторової інфраструктури, який реалізується шляхом будівництва, реконструкції і ремонту внутрішніх доріг автомобільного сполучення, розвитку мереж та інфраструктури залізниць для вантажних, пасажирських перевезень і туризму, формування транспортнологістичної прикордонної інфраструктури [4].

У «Програмі розвитку транскордонного співробітництва Закарпатської області на 20162020 pр.» зазначено на необхідність активізації соціально-економічного, науково-технічного, екологічного, культурного розвитку регіону за участю суб'єктів транскордонного співробітництва [3].

Акценти в Програмі поставлені на поглиблення співпраці в рамках Карпатського Єврорегіону, створення умов для заснування i функціонування спільних підприємств та утворення транскордонних економічних кластерів.

На особливе місце заслуговує «Програма розвитку прикордонної інфраструктури Закарпатської області на 2018 - 2020 роки», яка включає напрями комплексного підходу транспортної, логістичної, інфраструктурної складової розбудови та модернізації пунктів перетину кордону відповідно до європейських стандартів. Програмою передбачено ряд заходів щодо покращення транспортної інфраструктури в межах території досліджень. Це в першу чергу облаштування та реконструкція пункту пропуску «Ужгород - Вишнє-Нємецке»; реконструкція міжнародного пункту пропуску для автомобільного сполучення «Вилок»; реконструкція української частини пункту пропуску «Лужанка - Берегшурань»; реконструкція та відновлення залізничного сполучення Тересва - Кимпулунг ла Тиса та будівництво нового пункту пропуску Яблунівка Ремете (Гута).

Виконання вищезазначених пріоритетних напрямів розвитку транспортної мережі транскордонних територій Закарпатської області із суміжними територіями країн $\mathrm{CC}$ дають змогу виокремити їхні проблеми та перспективи розвитку. Розглянемо проблеми розвитку транспортної інфраструктури Закарпатської області рис.1.

Досліджуючи проблеми розвитку транспортної інфраструктури Закарпатської області, розглянемо перспективи розвитку транспортної інфраструктури Закарпатської області (рис. 2.) в контексті переваг географічного розташування Закарпаття, яке межує 3 чотирма державами такими як: 


\section{Проблеми розвитку транспортної інфраструктури Закарпатської області}

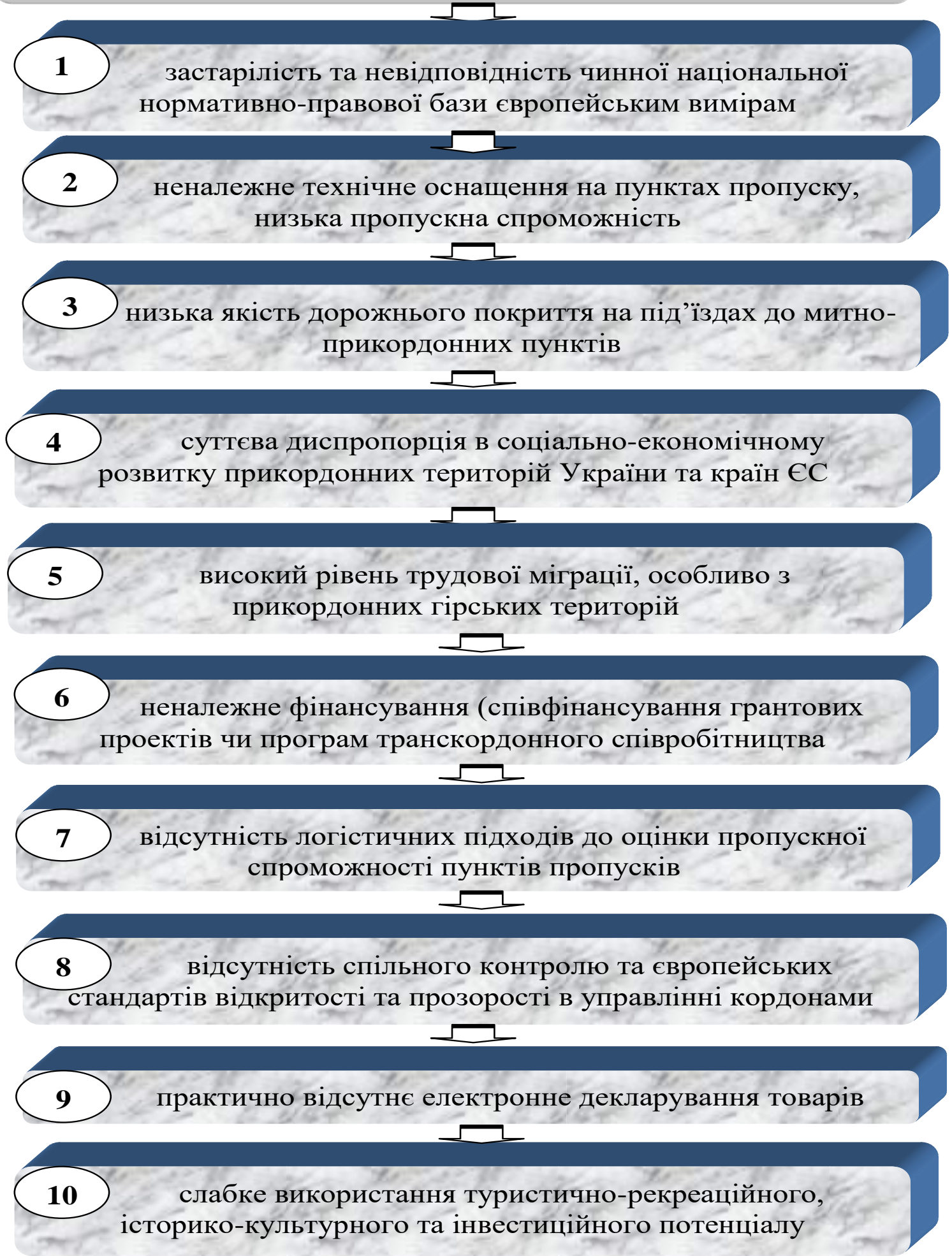

Рис. 1. Проблеми розвитку транспортної інфраструктури Закарпатської області (складено авторами)

Польща, Словаччина, Угорщина та Румунія, і які на міжнародних транзитних лініях сприяють в цілому розвитку i подальшому поглибленню міждержавного 


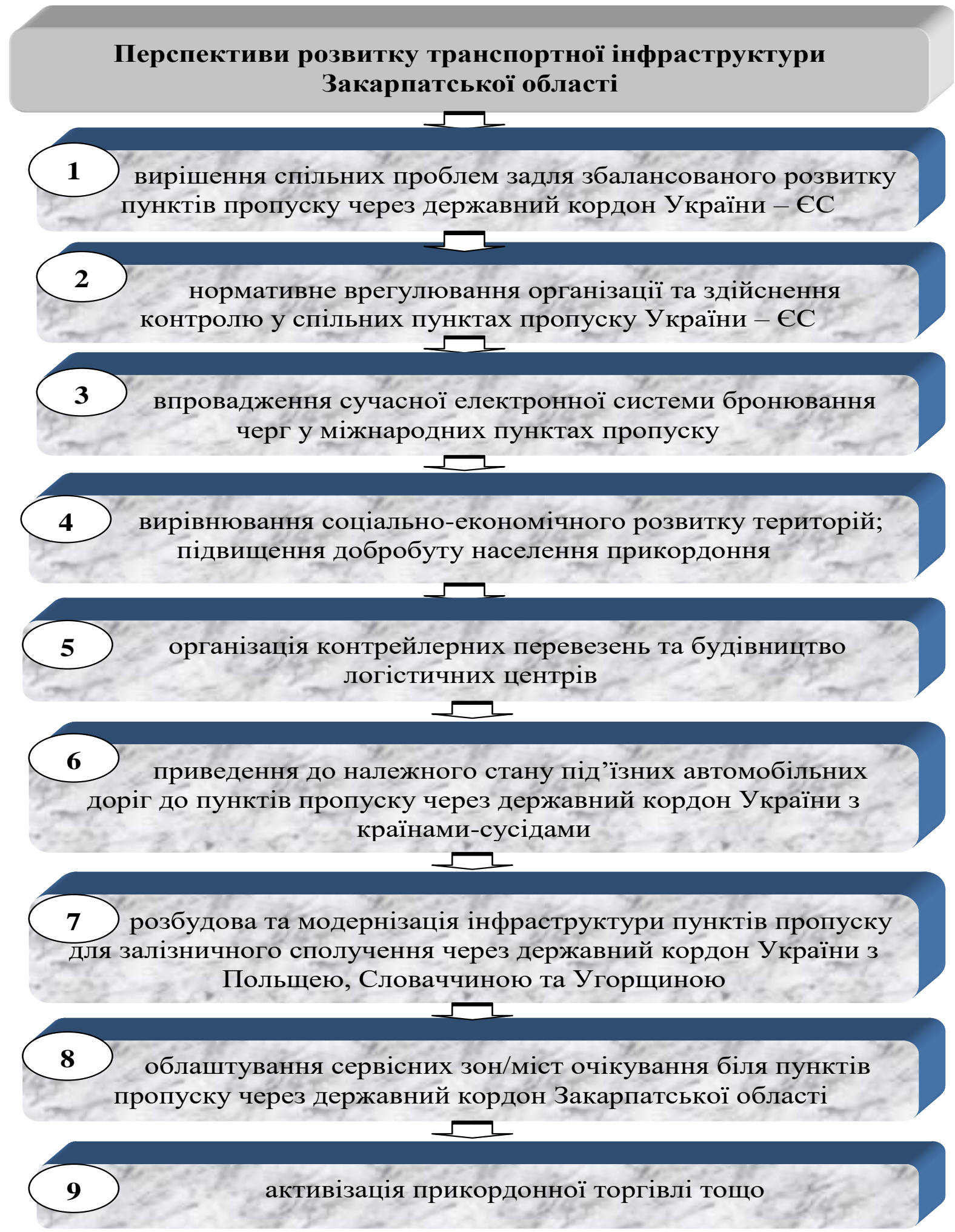

Рис. 2. Перспективи розвитку транспортної інфраструктури Закарпатської області (складено авторами)

Дослідження 3 перспектив розвитку транспортної інфраструктури Закарпатської області у частині зовнішньоекономічних зв'язків України, вимагає, значного покращення роботи транспорту в цілому та в прикордонних регіонах зокрема, в тому числі і на українських прикор66 донних переходах, доведення транспортних комунікацій до сучасного європейського та світового рівня, забезпечення якісного та нового транспортно-експедиційного обслуговування перевезень.

Висновки i перспективи подальших досліджень. Виконання вищезазначених 
пріоритетних напрямів розвитку транспортної мережі транскордонних територій Закарпатської області із суміжними територіями країн ЄС дали змогу виокремити їхні проблеми та перспективи розвитку, що дає можливість розробляти та реалізовувати спільні транскордонні стратегії, що сприятимуть зменшенню депресивних територій, покращення їхнього соціально-економічного розвитку в транскордонному просторі.

Сучасна транспортна мережа, iii інтеграція в мережу міжнародних транспортних коридорів, забезпечить формування конкурентоспроможної

\section{ПЕРЕЛІК ВИКОРИСТАНИХ ДЖЕРЕЛ}

1. Державна цільова економічна програма розвитку автомобільних доріг загального користування державного значення на 2018-2022 роки. - [Електронний ресурс]. - Режим доступу: https://www.kmu.gov.ua/npas/pro-zatverdzhennya-derzhavnoyi-cilovoyi-ekonomichnoyi-programi-rozvitkuavtomobilnih-dorig-zagalnogo-koristuvannya-derzhavnogo-znachennya-na-20182022-roki

2. Звіт Інституту регіональних досліджень імені М.І.Долішнього НАН України /Соціально-економічне обгрунтування перспектив розбудови мережі пунктів пропуску через державний кордон у Закарпатській області/ за ред. Х.Притули// Т.1, 2019. - с.88.

3. Програма розвитку транскордонного співробітництва Закарпатської області на 2016-2020 pp. [Електронний ресурс]. - Режим доступу: https://ips.ligazakon.net/document/view/za160439?ed=2016_12_07\&an=1

4. Регіональна стратегія розвитку Закарпатської області на період до 2020 року. - [Електронний ресурс]. Режим доступу: https://carpathia.gov.ua/storinka/regionalni-programy-rozvytku

5. Регламент ЄС №1931/2006 «Про місцевий прикордонний рух на зовнішніх сухопутних кордонах державчленів СС та про зміни положень Шенгенських Конвенцій» від 20.12.2006 p. - [Електронний ресурс]. - Режим доступу: https://zakon.rada.gov.ua/laws/show/994_919

6. Угода про Асоціацію між Україною, 3 однієї сторони, та Європейським Союзом, Європейським співтовариством з атомної енергії і їхніми державами-членами, з іншої сторони: Ратифікована Законом України № 1678-VII від 16.09.2014p. - [Електронний ресурс]. - Режим доступу: https://zakon.rada.gov.ua/laws/show/984_011/stru

\section{REFERENCES}

1. Державна цільова економічна програма розвитку автомобільних доріг загального користування державного значення на 2018-2022 роки. - Електронний ресурс]. - Режим доступу: https://www.kmu.gov.ua/npas/pro-zatverdzhennya-derzhavnoyi-cilovoyi-ekonomichnoyi-programi-rozvitkuavtomobilnih-dorig-zagalnogo-koristuvannya-derzhavnogo-znachennya-na-20182022-roki // Derzhavna tsilova ekonomichna prohrama rozvytku avtomobilnykh dorih zahalnoho korystuvannia derzhavnoho znachennia na 2018-2022 roky [State Targeted Economic Program for the Development of Public Roads of National Importance for 2018-2022]. Retrieved from https://www.kmu.gov.ua/npas/pro-zatverdzhennya-derzhavnoyi-cilovoyi-ekonomichnoyi-programirozvitku-avtomobilnih-dorig-zagalnogo-koristuvannya-derzhavnogo-znachennya-na-20182022-roki [in Ukrainian].

2. Соціально-економічне обгрунтування перспектив розбудови мережі пунктів пропуску через державний кордон у Закарпатській області / за ред. Х. Притули // Звіт Інституту регіональних досліджень імені М.I. Долішнього НАН України. - Т.1. - 2019. - 88 с.

Sotsialno-ekonomichne obgruntuvannia perspektyv rozbudovy merezhi punktiv propusku cherez derzhavnyi kordon u Zakarpatskii oblasti / za red. Kh. Prytuly // Zvit Instytutu rehionalnykh doslidzhen imeni M.I. Dolishnoho NAN Ukrainy. - T.1. - 2019. - $88 \mathrm{~s}$ [Socio-economic substantiation of prospects for building a network of border crossing points in the Transcarpathian region / edited by H. Prytula // Report of the Institute for Regional Studies named after M. Dolishnij of the National Academy of Sciences of Ukraine] [in Ukrainian].

3. Програма розвитку транскордонного співробітництва Закарпатської області на 2016-2020 pp. [Електронний ресурс]. - Режим доступу: https://ips.ligazakon.net/document/view/za160439?ed=2016_12_07\&an=1 // Prohrama rozvytku transkordonnoho spivrobitnytstva Zakarpatskoi oblasti na 2016-2020 rr. [Cross-border Cooperation Program for Transcarpathian Region for 2016-2020]. Retrieved from https://ips.ligazakon.net/document/view/za160439?ed=2016_12_07\&an=1 [in Ukrainian].

4. Регіональна стратегія розвитку Закарпатської області на період до 2020 року. - [Електронний ресурс]. Режим доступу: https://carpathia.gov.ua/storinka/regionalni-programy-rozvytku // Rehionalna stratehiia rozvytku Zakarpatskoi oblasti na period do 2020 roku [Transcarpathian Regional Development Strategy for the Period up to 2020]. Retrieved from https://carpathia.gov.ua/storinka/regionalni-programy-rozvytku [in Ukrainian].

5. Регламент ЄС №1931/2006 «Про місцевий прикордонний рух на зовнішніх сухопутних кордонах державчленів ЄС та про зміни положень Шенгенських Конвенцій» від 20.12.2006 p. - [Електронний ресурс]. - Режим доступу: https://zakon.rada.gov.ua/laws/show/994_919 // Rehlament YeS №1931/2006 «Pro mistsevyi prykordonnyi 
rukh na zovnishnikh sukhoputnykh kordonakh derzhav-chleniv YeS ta pro zminy polozhen Shenhenskykh Konventsii» vid 20.12.2006 r. [Regulations EU №1931/2006 " On local border traffic at the external land borders of EU Member States and amending the provisions of the Schengen Conventions"]. Retrieved from https://zakon.rada.gov.ua/laws/show/994_919 [in Ukrainian].

6. Угода про Асоціацію між Україною, з однієї сторони, та Європейським Союзом, Європейським співтовариством з атомної енергії і їхніми державами-членами, з іншої сторони: Ратифікована Законом України № 1678-VII від 16.09.2014 p. - [Електронний ресурс]. - Режим доступу: https://zakon.rada.gov.ua/laws/show/984_011/stru // Uhoda pro Asotsiatsiiu mizh Ukrainoiu, z odniiei storony, ta Yevropeiskym Soiuzom, Yevropeiskym spivtovarystvom z atomnoi enerhii i yikhnimy derzhavamy-chlenamy, z inshoi storony: Ratyfikovana Zakonom Ukrainy № 1678-VII vid 16.09.2014 r. [Association Agreement between Ukraine, of the one part, and the European Union, the European Atomic Energy Community, and their Member States, of the other part: has been ratified by Law of Ukraine No. 1678-VII of 16.09.2014.]. Retrieved from https://zakon.rada.gov.ua/laws/show/984_011/stru [in Ukrainian]. 